\title{
PERFORMANCE OF THE TREE-FEEDER ORGYIA LEUCOSTIGMA (LEPIDOPTERA:LIPARIDAE) ON ARTIFICIAL DIETS OF DIFFERENT WATER CONTENT: A COMPARISON WITH THE FORB-FEEDER MANDUCA SEXTA (LEPIDOPTERA:SPHINGIDAE)
}

\author{
Heidi M. Van't Hof $\dagger$ and Michael M. Martin* \\ Department of Biology, University of Michigan, Ann Arbor, MI 48109-1048, U.S.A.
}

(Received 26 September 1988; revised 28 January 1989)

\begin{abstract}
The egg-to-pupa growth rate of Orgyia leucostigma, which normally feeds on tree foliage, is an order of magnitude smaller than that of Manduca sexta, which normally fecds on herbaceous foliage, on four different nutrient-rich artificial diets. Relative growth rates of fifth-instar female $O$. leucostigma are only $37-53 \%$, and relative consumption rates only $40-50 \%$, of those of comparably sized third-instar $M$. sexta larvae. Similarly, respiration rates of $O$. leucostigma larvae are only $57.68 \%$ those of $M$. sexta larvae of equal size. The water budgets of the two species are very similar, and the two physiological adaptations contributing most to the efficient retention and use of water by larvae of both species on low-water die's are the resorption of water from the hindgut and the tolerance of reduced levels of tissue hydration. These results are consistent with the prediction of Mattson and Scriber that folivores adapted to feeding on nutrient-poor plants have inherently lower growth rates and lower metabolic rates than folivores adapted primarily to nutrient-rich plants, but it is not clear whether the differences reside primarily in thehavioural or physiological processes.
\end{abstract}

Key Word Index: Tobacco hornworm, Manduca sexta, white-marked tussock moth, Orgyia leucostigma, growth, nutritional indices, water budget, uric acid production, respiration rate, metabolic rate, adaptation to water stress

\section{INTRODUCTION}

Mattson and Scriber (1987) have suggested that "folivores adapted to feeding on nutrient-poor plants should be fundamentally different (morphologically, physiologically, and behaviourally) from folivores adapted primarily to nutrient-rich plants". This prediction is based on the observation that the relative growth rates of lepidopteran herbivores are strongly correlated with the nutritional quality of foliage, usually expressed as water and nitrogen content (Scriber and Feeny, 1979). Mattson and Scriber (1987) argue that there should be strong selection on traits that optimize relative growth rate (a correlate of fitness in Lepidoptera), and that these traits are likely to be different for species feeding on nutrient-rich and nutrient-poor foliage. As a consequence of this selection, they suggest that herbivores adapted to nutrient-poor foods, such as mature tree foliage, should have inherently lower growth rates and lower metabolic rates than herbivores adapted to nutrient-rich foods, such as herb or forb foliage. To date, however, there have been no direct tests of this prediction.

In this study we compare growth rates, feeding rates, respiration rates, uric acid production, and water budgets for larvae of the white-marked tussock moth, Orgyia leucostigma, and the tobacco horn-

*To whom reprint requests should be sent.

†To whom all other zorrespondence should be addressed. worm, Manduca sexta, on nitrogen-rich artificial diets containing 65 and $82 \%$ water. We have chosen diet water content as the nutritional variable for three reasons: (1) low foliar water content is one of the major characteristics of tree foliage contributing to its low nutritional quality (Mattson and Scriber, 1987), (2) water may be the primary limiting nutrient for tree-feeding folivores (Schroeder, 1986), and (3) low diet water content has been shown to reduce the growth rate of caterpillars (Scriber, 1977; Reese and Beck, 1978; Slansky and Scriber, 1985; Martin and Van't Hof, 1988; Timmins et al., 1988).

The natural diet of $O$. leucostigma includes the foliage of a large number of temperate tree species, including Abies, Aesculus, Betula, Larix, Malus, Platanus, Populus, Tilia, and Ulmus (Johnson and Lyon, 1976), whereas the food of $M$. sexta is the foliage of herbaceous Solanaceae. Thus, $O$. leucostigma and $M$. sexta are representative insect herbivores with nutrient-poor and nutrient-rich diets, respectively, and our results permit us to test the predictions of Mattson and Scriber (1987). Furthermore, by comparison of water budgets and the efficiency of water retention and use on high- and low-water diets we can determine whether differences in growth rate are attributable to specific physiological adaptations related to water use.

In particular, we have addressed the following questions: (1) Is $O$. leucostigma slower growing than $M$. sexta, even when larvae of the two species are presented with identical nutrient-rich artificial diets? 
(2) Does $O$. leucostigma have a lower metabolic rate than $M$. sexta? (3) Do $O$. leucostigma and $M$. sexta differ in their sensitivity to diet water content? (4) Do $O$. leucostigma and $M$. sexta larvae use different physiological mechanisms to enhance the retention and use of water on low-water diets?

\section{MATERIALS AND METHODS}

\section{Insects and artificial diets}

Larvae of the white-marked tussock moth, o. leucostigma (Lepidoptera: Liparidae), were reared on an artificial diet (Bio-Serv No. 9443) containing $75 \%$ water $\left(24^{\circ} \mathrm{C}, 16 \mathrm{~h}\right.$ light $-8 \mathrm{~h}$ dark) from eggs obtaincd from the Ontario Forest Pest Management Institute. Larvae of the tobacco hornworm, $M$. sexta (Lepidoptera: Sphingidae), were reared on an artificial diet (Bio-Serv No. 9783) containing $82 \%$ water $\left(24^{\circ} \mathrm{C}, 16 \mathrm{~h}\right.$ light $-8 \mathrm{~h}$ dark) from eggs obtained from the Carolina Biological Supply Company.

As body size can have a strong impact on the water relations of insects, the comparison of relative growth rates was made between fifth-instar $O$. leucostigma and third-instar $M$. sexta, which are of similar size. To make comparisons between non-ultimate instars of both species, only female fifth-instar $O$. leucostigma were used. The fifth-instar is penultimate for females and ultimate for males.

Bio-Serv Diet No. 9443, formulated for Orgyia, is a nutrient-rich diet containing $3.9 \%$ nitrogen, primarily casein, and $13 \%$ fibre. Bio-Serv Diet No. 9783, formulated for Manduca, is also a nutrient-rich diet containing $3.9 \%$ nitrogen, primarily casein, and $16 \%$ fibre. Both diets support growth rates equaling or exceeding those observed on foliage. The diet water contents of 82 and $65 \%$ were chosen to represent average water contents of herbaceous and woody plant foliage, respectively.

\section{Egg-to-pupa growth rates}

Newly emerged first-instar $O$. leucostigma and $M$. sexta larvae were placed in $25-\mathrm{ml}$ polystyrene cups containing either Bio-Serv Diet Nos 9443 or 9783 with a water content of either 82 or $65 \%$. The initial density of $O$. leucostigma was 15 larvae/cup, later adjusted to $3 /$ cup at the fourth-instar and $1 /$ cup at the fifth-instar. The initial density of $M$. sexta was 10 /cup, later adjusted to $1 /$ cup at the third-instar. Food was provided ad libitum and was changed every 3 days. Following hardening of the pupal cuticle, pupae were dried to constant mass in an oven at $75^{\circ} \mathrm{C}$ and weighed.

Single instar growth, food consumption and faecal production

Fifth-instar female $O$. leucostigma or third-instar $M$. sexta larvae of either sex, collected within one half hour of moulting, were weighed and placed individually into $10-\mathrm{ml}$ shell vials containing preweighed portions of artificial diet (either Bio-Serv Nos 9443 or 9783 ) initially containing either 82 or $65 \%$ water. The cube of diet was held in place within the vial by a stainless steel pin inserted through the diet into a rubber stopper wrapped in aluminum foil. In order to maximize the accuracy of the nutritional indices calculated from these measurements (Schmidt and Reese, 1986), the quantity of food supplied was limited such that at least $60 \%$ was consumed by the larvae during the instar. The vials containing the larvae and food were placed in a growth chamber $\left(24^{\circ} \mathrm{C}, 16 \mathrm{~h}\right.$ light $-8 \mathrm{~h}$ dark) until the larvae moulted to the sixth-instar. As soon as the larvae had moulted to the sixth-instar, the larvae, faeces and uneaten food were separated and dried to constant mass in an oven at $75^{\circ} \mathrm{C}$. The dry mass of larvae at the beginning of the experiment was estimated from a wet mass vs dry mass calibration curve obtained using newly moulted fifth-instar $O$. leucostigma and third-instar $M$. sexta comparable to those used in the experiment. Likewise, the initial dry mass of the food was estimated from a wet mass vs dry mass calibration curve obtained by drying additional portions of the artificial diet.

\section{Nutritional indices}

Nutritional indices were calculated according to Waldbauer (1968). All indices were calculated on a dry mass basis. Relative rates of consumption and growth were based on the arithmetic mean of initial and final larval dry mass. Abbreviations: RCR, relative consumption rate; $R G R$, relative growth rate; AD, approximate digestibility or assimilation efficiency; ECI, efficiency of conversion of ingested food or gross growth efficiency; ECD, efficiency of conversion of digested food or net growth efficiency.

$$
\begin{aligned}
\mathrm{RGR} & =\frac{\text { larval mass gained }}{\text { average larval mass during instar } \times \text { days }} \\
\mathrm{RCR} & =\frac{\text { mass of food ingested }}{\text { average larval mass during instar } \times \text { days }} \\
\mathrm{AD} & =\frac{\text { mass of food ingested }- \text { mass of frass }}{\text { mass of food ingested }} \\
\mathrm{ECD} & =\frac{\text { larval mass gained }}{\text { mass of food ingested }- \text { mass of frass }} \\
\mathrm{ECI} & =\frac{\text { larval mass gained }}{\text { mass of food ingested }}
\end{aligned}
$$

Statistical comparisons of the nutritional indices for larvae on each diet were made using a Mann-Whitney U Test.

\section{Respiration of rates}

Newly moulted fifth-instar female $O$. leucostigma larvae were fed in shell vials containing artificial diets of either 82 or $65 \%$-water for $24 \mathrm{~h}$ prior to the measurement of respiration rates. Seven larvae from each diet were weighed and placed singly in 12- or $22-\mathrm{ml}$ respirometer flasks containing $0.5 \mathrm{ml}$ of distilled water in the side arm and $0.4 \mathrm{ml}$ of $10 \%$ potassium hydroxide in the centre well (Gilson Respirometer GR14). Larvae were sedentary in the flasks. Following a 1 -h equilibration period at $25^{\circ} \mathrm{C}$, oxygen consumption at $25^{\circ} \mathrm{C}$ was measured for $1 \mathrm{~h}$. Larvae, and faeces if present, were removed from the flask and weighed, then oven-dried to constant mass at $75^{\circ} \mathrm{C}$ and reweighed. The water contents of 24-hold larvae were 85.0 and $82.4 \%$ on the $82 \%$-water 
Table 1. Eggg-to-pupa growth rates, dry mass gain, and time to pupation (mean and SE) of Orgyia leucostigma and Manduca sexta on artificial diets with initial water contents of 82 or $65 \%$

\begin{tabular}{|c|c|c|c|c|}
\hline \multirow[b]{2}{*}{ Species } & \multicolumn{2}{|c|}{ Orgyia diet (Bio-Serv No. 9443) } & \multicolumn{2}{|c|}{ Manduca diet (Bio-Serv No. 9783) } \\
\hline & $82 \%$-water & $65 \%$-water & $82 \%$-water & $65 \%$-water \\
\hline \multicolumn{5}{|l|}{ O. leucostigma } \\
\hline Growth rates (g/day) & $0.003 \pm 0.0002$ & $0.003 \pm 0.0002$ & $0.003 \pm 0.0003$ & $0.003 \pm 0.0002$ \\
\hline Mass gain (g) & $0.07+0.005$ & $0.07 \pm 0.007$ & $0.07 \pm 0.006$ & $0.08 \pm 0.006$ \\
\hline Time (days) & $23.8 \pm 0.38$ & $26.0 \pm 0.48$ & $20.4 \pm 0.42$ & $23.1 \pm 0.36$ \\
\hline$n$ & $\overline{66}$ & 39 & 46 & 63 \\
\hline \multicolumn{5}{|l|}{ M. sexta } \\
\hline Growth rates ( $\mathrm{g} /$ day) & $0.051 \pm 0.0110$ & $0.050 \pm 0.0067$ & $0.051 \pm 0.0051$ & $0.050 \pm 0.0067$ \\
\hline Mass gain $(\mathrm{g})$ & $1.47 \pm 0.319$ & $1.45 \pm 0.209$ & $1.39 \pm 0.164$ & $1.34 \pm 0.198$ \\
\hline Time (days) & $28.9 \pm 2.16$ & $29.1 \pm 2.41$ & $27.4 \pm 3.13$ & $27.0 \pm 1.72$ \\
\hline$n$ & 14 & 27 & $\overrightarrow{14}$ & 35 \\
\hline
\end{tabular}

Mann-Whitney U test).

diet and $65 \%$-water diet, respectively. Linear regressions of the natural logarithm of respiration ratc on the natural logarithm of body dry mass were calculated. Linear regressions for each diet were compared by an analysis of covariance, which identifies significant shifts in the $y$-intercept of the regression equations. Respiration rates were calculated for a $15 \mathrm{mg}$ (dry mass) larva using the regression equations for each diet. Because error around an estimate of $Y$ from a given $X$ is difficult to quantify for anti-log expressions of $\log$ transformed data, the estimated respiration rates are reported both in log form (mean and $95 \%$ confidence interval) and in anti-log form (mean).

\section{Uric acid analysis}

Fifth-instar $O$. lencostigma larvae used in the nutritional indices and the faeces they produced were pooled for each dist, oven dried $\left(70^{\circ} \mathrm{C}\right)$ to constant mass, and ground to a powder in liquid nitrogen with a mortar and pestle. The dried ground larval biomass was defatted by extracting once with chloroformmethanol $(2: 1, \mathrm{v} / \mathrm{v})(1.5 \mathrm{ml} / 5 \mathrm{mg})$. Uric acid analyses were run in triplicate on subsamples taken from the pooled dried grourd samples of larvae and faeces. Uric acid was determined by adapting the method of Bhattacharya and Waldbauer (1969) and Sigma Procedure No. 292-UV (Martin and Van't Hof, 1988).

\section{The water hudget}

A water budget was constructed from experimentally determined values of water gained by ingestion and respiration, lost by egestion and transpiration, and committed to growth, as described by Martin and Van't Hof (1988). The average water content of the diet during the feeding phase of the fifth-instar, determined by averaging the water content at 0,24 , 48 , and $72 \mathrm{~h}$ into the instar, was 80.2 and $64.4 \%$ for the high-water and low-water diets, respectively. In calculating the amount of water allocated to growth, it is necessary to recognize two components of growth: (1) the adjustment of the level of body hydration from that at the beginning of the instar to that at the end, and (2) the synthesis of new tissue. The amount of water required to adjust the initial hydration level to the final hydration level is a positive number for larvae on the high-water diet, since their hydration level increases during the fifthinstar from 80.8 to $85.1 \%$, and a negative number for larvae on the low-water diet since their hydration level decreases from 80.8 to $79.6 \%$.

\section{RESULTS}

Growth and consumption rates of $O$. leucostigma and $M$. sexta

The egg-to-pupa growth rate of $O$. leucostigma is an order of magnitude smaller than that of $M$. sexta on every diet tested, whether it is formulated specifically for Orgyia or Manduca, or whether it contains 82 or $65 \%$ water (Table 1).

This difference in growth rate between the two species is also apparent when single-instar relative growth rates of similarly sized larvae are compared (Table 2). The relative growth rate of fifth-instar female 0 . leucostigma larvae is $37-53 \%$ lower than that of similar sized third-instar $M$. sexta larvae on the four diets tested. The major factor contributing to the slower growth of $O$. leucostigma is its lower relative consumption rate, which in $O$. leucostigma is $40-45 \%$ lower than that of $M$. sexta.

Diet water content has a different effect on the growth rate of the two species. The relative growth rate of fifth-instar female $O$. leucostigma larvae is the same on artificial diets containing 65 and $82 \%$ water, whereas that of third-instar $M$. sexta larvae is significantly lower on low-water diets (Table 2). The lack of dependence of this growth rate on diet water content for $O$. leucostigma larvae is a consequence of small but significant increases in approximate digestibility and relative consumption rate that compensate for a small reduction in the efficiency of conversion of digested food to growth on the low-water diet (Table 3).

\section{Respiration rates}

Fifth-instar $O$. leucostigma larvae respire at the same rate on a diet containing $65 \%$ water as on a diet containing $82 \%$ water (Fig. 1). Larvae weighing $15 \mathrm{mg}$ (dry mass) are calculated to respire at rates of $4.2 \pm 0.07$ and $4.2 \pm 0.11 \ln \mu 1 \mathrm{O}_{2} / \mathrm{h}$ (mean and $95 \%$ confidence interval) or 70.2 and $68.2 \mu 1 \mathrm{O}_{2} / \mathrm{h}$ on diets of 82 and $65 \%$-water, respectively. This equality in the respiration rates on the two diets holds over the cntire size range of mid-fifth-instar female larvae. The larvae used in these experiments were in the active feeding stage of the fifth-instar, but were not allowed 
Table 2. Relative growth rate and relative consumption rate (mean and SE) of fifth-instar female Orgyia leucostigma larvae and third-instar Manduca sexta larvae of both sexes on artificial diets with initial water contents of 82 and $65 \%$

\begin{tabular}{|c|c|c|c|c|}
\hline \multirow[b]{2}{*}{ Species } & \multicolumn{2}{|c|}{$\begin{array}{c}\text { Orgyia diet } \\
\text { (Bio-Serv No. 9443) }\end{array}$} & \multicolumn{2}{|c|}{$\begin{array}{c}\text { Manduca diet } \\
\text { (Bio-Serv No. 9783) }\end{array}$} \\
\hline & $82 \%$-water & $65 \%$-water & $82 \%$-water & $65 \%$-water \\
\hline \multicolumn{5}{|c|}{$\begin{array}{l}\text { Relative growth rates } \\
\text { (mg/day/mg) }\end{array}$} \\
\hline o. leucostigma & $0.24 \pm \frac{0.040}{(52)}$ & $0.24 \pm 0.040$ & $\frac{0.23 \pm 0.041}{(50)}$ & $\begin{array}{c}0.25 \pm 0.041 \\
(49)\end{array}$ \\
\hline M. sexta & $0.44 \pm 0.007$ & $0.38 \pm 0.008$ & $0.49 \pm 0.008$ & $\frac{0.44 \pm 0.008}{(26)}$ \\
\hline \multicolumn{5}{|c|}{$\begin{array}{l}\text { Relative consumption rates } \\
(\mathrm{mg} / \mathrm{day} / \mathrm{mg})\end{array}$} \\
\hline o. leucostigma & $1.08 \pm 0.023$ & $1.14 \pm \underset{(55)}{0.019}$ & $0.97 \underset{(50)}{ \pm 0.020}$ & $0.98 \underset{(49)}{ \pm 0.019}$ \\
\hline M. sexta & $\frac{1.78 \pm 0.034}{(34)}$ & $\frac{1.86 \pm 0.052}{(35)}$ & $1.74 \pm 0.040$ & $1.77 \pm 0.037$ \\
\hline
\end{tabular}

The number of replicates is indicated in parentheses. The relative growth rate and relative consumption rate of $O$. leucostigma are significantly lower than those of $M$. sexta on all diets $(P<0.0001$ Mann-Whitney $U$ test). For both Bio-serv diets, the relative growth rate of $M$. sexta is significantly lower when the diets contain $65 \%$ water rather than $82 \%$ water $(P<0.0001$ Mann-Whitney U test $)$.

Table 3. Nutritional indices (mean and SE) of fifth-instar female Orgyia leucostigma larvae reared on artificial diets (Bio-Serv No. 9443) with initial water contents of 82 or $65 \%$

\begin{tabular}{|c|c|c|c|}
\hline \multirow{2}{*}{$\begin{array}{l}\text { Nutritional } \\
\text { index* }\end{array}$} & \multicolumn{2}{|c|}{ Initial water content of diet } & \multirow[b]{2}{*}{$P$ value } \\
\hline & $82 \%$ & $65 \%$ & \\
\hline RGR (mg/day/mg) & $0.24 \pm 0.006$ & $0.24 \pm 0.005$ & 0.6006 \\
\hline $\mathrm{RCR}$ (mg/day/mg) & $1.08 \pm 0.023$ & $1.14 \pm 0.019$ & 0.0102 \\
\hline ECI $(\%)$ & $22.5 \pm 0.33$ & $20.7 \pm 0.33$ & 0.0003 \\
\hline AD $(\%)$ & $46.8 \pm 0.49$ & $50.9 \pm 0.41$ & 0.0001 \\
\hline $\operatorname{ECD}(\%)$ & $48.1 \pm 0.75$ & $40.7 \pm 0.64$ & 0.0001 \\
\hline
\end{tabular}

Significance levels are given for Mann-Whitney $U$ tests. The number of replicates was 52 and 55 for the $82 \%$ - and $65 \%$-water diets, respectively.

-For abbreviations, see Materials and Methods.

to feed for $1 \mathrm{~h}$ prior to the initiation of the measurement of respiration or during the hour when the measurement was made. Thus, the observed metabolic rates do not include feeding costs or other food acquisition costs. The metabolic rates we have measured are best interpreted as a summation of maintenance metabolism (basal metabolism), the metabolism involved in growth processes, and the metabolic costs associated with the processing of ingested and assimilated food.

\section{Uric acid production by $O$. leucostigma}

Total uric acid production is similar for 0 . leucostigma larvae from the high- and low-water diets, although its distribution between faeces and larval tissue is different (Table 4). The larvae on the high-water diet excrete more uric acid in their faeces, while the larvae on the low-water diet accumulate more in their tissues. Since the synthesis of uric acid is a highly endergonic process, the lack of increase in uric acid production by $O$. leucostigma larvae on the low-water diet is consistent with the lack of increase in metabolic rate.

\section{The water budget}

Food is the major source of water for $O$. leucostigma larvae, with metabolic water making only a minor contribution to the total input (Table 5). Larvae on the high-water diet gain 2.8 times as much

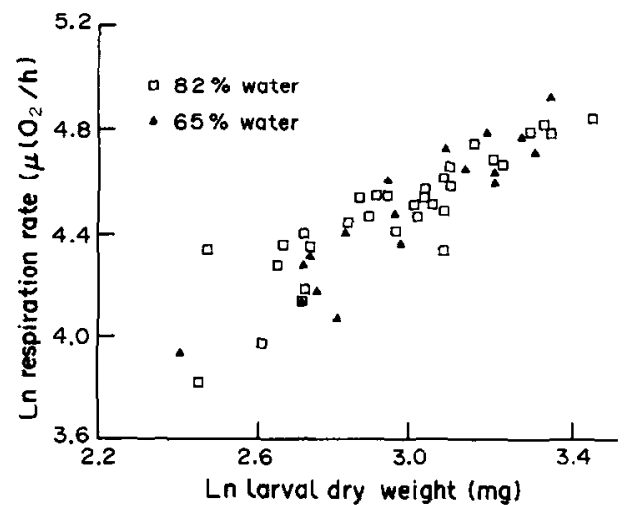

Fig. 1. Respiration rate as a function of larval dry mass for fifth-instar female Orgyia leucostigma following ingestion of artificial diets of $82 \%(\square)$ or $65 \%$ (A) water. Regression equations for natural log transformed data are $y=0.815 x+2.045$ and $y=0.899 x+1.788$ for diets of 82 and $65 \%$ water, respectively. Larvae weighing $15 \mathrm{mg}$ (dry mass) are calculated to respire at a rate of $4.2(0.07)$ and 4.2 (0.11) $\ln \mu 1 \mathrm{O}_{2} / \mathrm{h}$ (mean and $95 \%$ confidence interval) or 70.2 and $68.2 \mu 1 \mathrm{O}_{2} / \mathrm{h}$ on diets of 82 and $65 \%$-water, respectively. Analysis of covariance reveals no significant differences in the slopes or intercepts of the two regression equations.

water from their food as larvae on the low-water diet $(283.4$ vs $101.0 \mathrm{mg}$ ). Faecal excretion is the main avenue by which water is lost, but a significant amount is also lost by transpiration. Larvae on the

Table 4. Uric acid production (mean and SE) by fifth-instar female Orgyia leucostigma larvae reared on artificial diets (Bio-Serv No. 9443 ) with initial water contents of 82 and $65 \%$

\begin{tabular}{ccc}
\hline & \multicolumn{2}{c}{ Diet water content } \\
\cline { 2 - 3 } Source of uric acid & $82 \%$ & $65 \%$ \\
\hline Faeces (mg) & $0.15 \pm 0.007$ & $0.10 \pm 0.004$ \\
$(\%)$ & $0.43 \pm 0.027$ & $0.32 \pm 0.017$ \\
Larvae (mg) & $0.10 \pm 0.006$ & $0.12 \pm 0.005$ \\
$(\%)$ & $0.67 \pm 0.031$ & $0.96 \pm 0.026$ \\
Total (mg) & $0.25 \pm 0.012$ & $0.22 \pm 0.009$ \\
\hline
\end{tabular}

Individuals and faeces from each treatment were pooled at the end of the instar $(n=47$ for the $82 \%$-water diet and 54 for the $65 \%$-water diet). The reported mean is based upon three determinations on sub-samples from the pooled sample. 
Table 5. Water budgets of fifth-instar female Orgyia leucostigma larvae reared on artificial diets (Bio-Serv No. 9443) with initial water contents of 82 or $65 \%$, and average water contents of 80.2 or $64.6 \%$

\begin{tabular}{|c|c|c|}
\hline \multirow{2}{*}{$\begin{array}{l}\text { Source of water } \\
\text { gain or loss }\end{array}$} & \multicolumn{2}{|c|}{ Water gained or lost (mg) } \\
\hline & High-water diet & Low-water diet \\
\hline \multicolumn{3}{|l|}{ Gain: } \\
\hline Food & $283.4 \pm 13.31$ & $101.0 \pm 4.41$ \\
\hline Respiration & $4.3 \pm 0.21$ & $4.0 \pm 0.18$ \\
\hline Adjustment of initial & & \\
\hline level of larval hydration & - & $2.8 \pm 0.62$ \\
\hline Total & $287.7 \pm 13.48$ & $107.8 \pm 4.85$ \\
\hline \multicolumn{3}{|l|}{ Loss: } \\
\hline Faeces & $148.5 \pm 7.11$ & $29.3 \pm 1.20$ \\
\hline Transpiration & $25.9 \pm 1.36$ & $20.3 \pm 0.96$ \\
\hline Adjustment of initial & & \\
\hline level of larval hydration & $12.7 \pm 1.20$ & - \\
\hline Growth & $82.4 \pm 4.86$ & $49.6 \pm 2.06$ \\
\hline Total & $269.5 \pm 13.09$ & $99.2 \pm 3.90$ \\
\hline
\end{tabular}

Consult Martin and Van't Hof (1988) for the procedures used to calculate the water gained or lost by each pathway. Values are means and SE, and the number of replicates was 47 for the $82 \%$-water diet and 54 for the $65 \%$-water diet.

high-water diet lose five times as much water in the faeces than larvae on the low-water diet (148.5 vs $29.3 \mathrm{mg}$ ). Changes in the level of tissue hydration between the beginning and end of the instar also affect the amount of water available for the synthesis and hydration of new tissue. Larvae on the low-water diet have a lower bocly water content at the end of the instar than at the beg,inning ( 79.6 vs $80.8 \%$ ), and thus have a small additional amount of water available for the hydration of newly synthesized tissue. In contrast, larvae on the high-water diet have a higher body water content at the end of the instar than at the beginning $(85.1$ vs $30.8 \%$ ), thus removing a small amount of water from the pool available for the hydration of new tissue. After all avenues of water gain have been taken into account, the larvae on the low-water diet gain only $37.5 \%$ as much water as the larvae on the high-water diet (107.8 vs $287.7 \mathrm{mg})$.

Larvae from the low-water diet retain and use water much more efficiently than larvae from the high-water diet (Table 6). They use $46.0 \%$ of the water available to them for the hydration of new tissue ( 49.6 out of $107.8 \mathrm{mg}$ ), while the larvae on the high-water diet use only $28.6 \% \quad(82.4$ out of $287.7 \mathrm{mg}$ ). The greater efficiency of the larvae from the low-water diet in retaining the water they have

Table 6. Measures of efficiency (mean and SE) with which fifth-instar female Orgyia leucostigma larvae retain and use water for growth when reared on artificial diets (Bio-Serv No. 9443) with initial water contents of 82 and $65 \%$

\begin{tabular}{|c|c|c|}
\hline \multirow[b]{2}{*}{ Measure } & \multicolumn{2}{|c|}{ Initial water content of diet } \\
\hline & $82 \%$ & $65 \%$ \\
\hline $\begin{array}{l}\text { Amount of available watser that } \\
\text { is used for growth }(\%) \\
\text { Water content of faeces }(\%)\end{array}$ & $\begin{array}{l}28.6 \\
80.1 \pm 0.19 \\
n=5\end{array}$ & $\begin{array}{l}46.0 \\
48.0 \pm 0.21 \\
n=5\end{array}$ \\
\hline $\begin{array}{l}\text { Difference between water } \\
\text { content }(\%) \text { of food and faeces } \\
\text { Water content of larvae }(\%)\end{array}$ & $\begin{array}{c}1.9 \\
85.1 \pm 0.30 \\
n=47\end{array}$ & $\begin{array}{l}17.0 \\
79.6 \pm 0.35 \\
n=54\end{array}$ \\
\hline $\begin{array}{l}\text { Dry weight (mg) of new larval } \\
\text { tissue that can be synthesized } \\
\text { when } 1 \mathrm{mg} \text { of water is available } \\
\text { to hydrate the new tissue }\end{array}$ & 0.175 & 0.256 \\
\hline
\end{tabular}

gained is due to their ability to produce much drier faeces than larvae from the high-water diet (48.0 vs $80.1 \%$ water, $P<0.0001$ Mann-Whitney $U$ test). On the high-water diet, the water content of the faeces differs very little from the water content of the diet. On the low-water diet, however, the water content of the faeces is much less than that of the food. These results indicate a significant capacity of $O$. leucostigma larvae to resorb water from the contents of the rectum when their diet is low in water.

The water content of larvae on the low-water diet is significantly lower than the water content of larvae on the high-water diet $(79.6$ vs $85.1 \%, P<0.0001$ Mann-Whitney U test) (Table 6). As a consequence of the lower level of tissue hydration, larvae on the low-water diet can synthesize $46 \%$ more new tissue using a given amount of water than their counterparts on the high-water diet $(0.256$ vs $0.175 \mathrm{mg}$ dry mass tissue per mg water).

\section{DISCUSSION}

In this study and our earlier one (Martin and Van't Hof, 1988) we have measured growth rates, metabolic rates, uric acid production and water budgets of the white-marked tussock moth, $O$. leucostigma, and the tobacco hornworm, $M$. sexta, on diets of different water content. Our results permit us to test some of the predictions of Mattson and Scriber (1987) concerning evolved differences between herbivores adapted to feed on nutrient-poor and nutrient-rich plants. For ease of reference in the discussion which follows, we have summarized some of the pertinent data for $O$. leucostigma and $M$, sexta in a single table (Table 7).

The tree-feeder $O$. leucostigma is slower growing than the forb-feeder $M$. sexta. On all diets tested, $O$. leucostigma larvae consume their food and grow significantly more slowly than $M$. sexta larvae (Tables 1 and 2). The tree-feeder also has a lower metabolic rate than the forb-feeder. Respiration rates of $O$. leucostigma larvae are only $57-68 \%$ those of $M$. sexta larvae (Fig. 1, Table 7).

It is not possible in this study to determine whether the inherently lower growth rate of the tree-feeder is a consequence of physiological or behavioural limitations. It is difficult to sort out cause and effect in the relationship between growth, feeding and metabolic rates. It is possible that $O$. leucostigma do not have the same physiological capacity for rapid growth as $M$. sexta. In this case, the lower metabolic rate would reflect this physiological limitation, and the reduced consumption rate would be a behavioural adaptation to avoid the ingestion of a nutrient surplus requiring excretion at a metabolic cost. On the other hand, it is also possible that $O$. leucostigma larvae possess the same physiological capacity for rapid growth as $M$. sexta, but grow more slowly simply because they feed more slowly and are nutrient limited. In this case, the lower metabolic rate would reflect the reduced metabolic demands of a lower growth rate, but not a lower capacity for growth. Thus, it is not clear whether the "inherently" lower growth rate of the tree-feeder is a consequence of a physiological or a behavioural limitation. 
Table 7. Performance values (mean and SE) of fifth-instar female Orgyia leucostigma and third-instar Manduca sexta larvae of both sexes on artificial diets with initial water contents of 82 and $65 \%$

\begin{tabular}{|c|c|c|c|c|}
\hline & \multicolumn{2}{|c|}{ O. leucostigma } & \multicolumn{2}{|c|}{$M$. sexta } \\
\hline & $82 \%$-water & $65 \%$-water & $82 \%$-water & $65 \%$-water \\
\hline $\begin{array}{l}\text { Growth rate, egg-to-pupa } \\
\text { (g/day) }\end{array}$ & $0.003 \pm 0.0002$ & $0.003 \pm 0.0002$ & $0.051 \pm 0.0014$ & $0.050 \pm 0.0011$ \\
\hline $\begin{array}{l}\text { Relative growth rate, single instar } \\
(\mathrm{mg} / \mathrm{day} / \mathrm{mg})\end{array}$ & $0.24 \pm 0.040$ & $0.24 \pm 0.040$ & $0.49 \pm 0.008$ & $0.44 \pm 0.008$ \\
\hline $\begin{array}{l}\text { Relative consumption rate, single instar } \\
(\mathrm{mg} / \mathrm{day} / \mathrm{mg})\end{array}$ & $1.08 \pm 0.023$ & $1.14 \pm 0.019$ & $1.74 \pm 0.040$ & $1.77 \pm 0.037$ \\
\hline $\begin{array}{l}\text { Respiration rate of } 15 \mathrm{mg} \text { larva (dry mass) } \\
\quad\left(\ln \mu 1 \mathrm{O}_{2} / \mathrm{h}\right) \\
\quad\left(\mu 1 \mathrm{O}_{2} / \mathrm{h}\right) \\
\text { Uric acid produced (mg/larva/instar) } \\
\text { Water content of larvae }(\%) \\
\text { Efficiency of water use for growth* } \\
\text { Water content of faeces }(\%)\end{array}$ & $\begin{array}{l}4.2(0.07) \\
70.2 \\
0.25 \pm 0.012 \\
85.1 \pm 0.30 \\
0.175 \\
80.1 \pm 0.19\end{array}$ & $\begin{array}{c}4.2(0.11) \\
68.2 \\
0.22 \pm 0.009 \\
79.6 \pm 0.35 \\
0.256 \\
48.0 \pm 0.21\end{array}$ & $\begin{array}{l}4.6(0.09) \\
103.2 \\
0.54 \pm 0.020 \\
88.1 \pm 0.17 \\
0.135 \\
77.3 \pm 0.57\end{array}$ & $\begin{array}{c}4.8(0.06) \\
118.7 \\
1.35 \pm 0.044 \\
81.3 \pm 0.35 \\
0.230 \\
48.1 \pm 1.39\end{array}$ \\
\hline
\end{tabular}

*Amount of new larval tissue (dry mass) that can be synthesized when $1 \mathrm{mg}$ of water is available to hydrate new tissue (mg).

For respiration rate, $95 \%$ confidence intervals are provided in parentheses. The diet for $O$. leucostigma was Bio-Serv No. 9443 ; for $M$. sexta, Bio-Serv No, 9783. Except for growth rate (egg-to-pupa), relative growth rate, and relative consumption rate, all data for $M$. sexia are from Martin and Van't Hof (1988).

The tree-feeder and the forb-feeder differ in their sensitivity to diet water content. Whereas the relative growth rate of $O$. leucostigma larvae is the same on high- and low-water diets, that of $M$. sexta larvae is $11-16 \%$ higher on the high-water diet compared with the low-water diet (Tables 1, 2 and 7). Thus $M$. sexta is both faster growing and better able to increase its growth rate in response to an increase in the water content of its food than $O$. leucostigma, which appears to lack the necessary biochemical, physiological or behavioural traits to benefit from the consumption of a more nutrient-rich high-water diet. The treefeeder is, therefore, both slower growing and less flexible in its response to an improvement in diet quality.

The difference in the response of growth rate to a low-water diet has important implications for nitrogen budgets, uric acid production and metabolic rate of the two species. On the low-water diet, $M$. sexta larvae accumulate assimilated nitrogen in excess of what can be used in growth because their growth is water limited. As a result, they produce 2.5 times as much uric acid and respire at a rate $16 \%$ higher on the low-water diet compared with the high-water diet (Table 7). By contrast, $O$. leucostigma larvae produce no more uric acid and respire at no higher rate on the low-water diet than on the high-water diet (Table 7), indicating that nitrogen acquisition and use are regulated in a way that avoids the assimilation of a surplus and the attendant metabolic cost associated with its excretion.

The water budgets of $O$. leucostigma and $M$. sexta on high- and low-water diets are very similar. For both species, food is the major source of larval water gain (Table 5 and Martin and Van't Hof, 1988). As a consequence, the total water input is substantially smaller for larvae on the low-water diet than for larvae on the high-water diet. For both species, growth, excretion, and evaporation are the major avenues of larval water loss. Because growth of the larvae on the low-water diet can be water-limited (Schroeder, 1986; Martin and Van't Hof, 1988), there should be strong selection for physiological mechanisms that enhance the efficient retention and use of water. In both species, the two physiological adapta- tions contributing most to the efficient use of water by larvae on the low-water diet are an ability to tolerate a lower level of body hydration and an ability to resorb significant amounts of water from the contents of the rectum (Table 7).

A lower level of body hydration increases the efficiency with which water is used in growth, because it permits the hydration of more new tissue with a given amount of water. The hydration level of $O$. leucostigma larvae is significantly lower than that of $M$. sexta larvae on both low- and high-water diets $(P<0.0001$, Mann-Whitney $U$ test) (Table 7). As a result, $O$. leucostigma larvae are able to hydrate 11 and $30 \%$ more new tissue per unit quantity of water than $M$. sexta on the low- and high-water diets, respectively. In terms of the ability to adjust and tolerate a reduced body water content, the tree-feeder $O$. leucostigma is clearly better adapted than the forb-feeder $M$. sexta to deal with the water stress imposed by a low intake of water from the diet. The two species do not differ, however, in their ability to resorb water from the rectum (Table 7). On the $65 \%$-water diet, the larvae of both species produce faeces containing $48 \%$ water.

Thus, $O$. leucostigma and $M$. sexta larvae employ the same physiological adaptations to enhance the retention and use of water on a low-water diet, and therefore do not differ fundamentally with respect to physiological adaptations to dietary water limitation. The ability of $O$. leucostigma to tolerate a lower level of body hydration suggests that tree-feeders may make more efficient use of retained water than forbfeeders, but information on additional species is required to determine whether this is a general pattern.

In summary, the lower rates of growth, consumption and metabolism observed for the tree-feeder $O$. leucostigma, compared to those of the forb-feeder $M$. sexta, are entirely consistent with the prediction of Mattson and Scriber (1987) that herbivores adapted to nutrient-poor foods should be slower growing and have lower metabolic rates than species adapted to nutrient-rich foliage. Furthermore, the herb-feeder is able to respond to an increase in diet quality (i.e. an increase in water content) by increas- 
ing its growth rate whereas the tree-feeder cannot. We have identified and comparcd scveral physiological processes important to the use of poorly hydrated food, and have found that $O$. leucostigma and $M$. sexta larvae do not employ fundamentally different physiological adaptations to enhance the retention and use of water. On the low-water diet, the larvae of both species rely upon rectal resorption to retain water and the tolerance of lower body water content to permit more growth per unit water retained. Thus, our findings confirm the prediction of Mattson and Scriber that herbivores adapted to nutrient-poor diets have inherently lower rates of growth and metabolism than herbivores adapted to nutrient-rich diets, but it is not clear whether the differences reside primarily in physiological or behavioural processes.

Acknowledgements-We thank the National Science Foundation for a grant (BSR-8421268) to M.M.M., which supported this research. We also thank Dale Grisdale of the Ontario Forest Pest Management Institute for eggs of O. leucostigma.

\section{REFERENCES}

Bhattacharya A. K. and G. P. Waldbauer (1969) Quantitative determination of uric acid in insect feces by lithium carbonate extraction and the enzymatic-spectrophotometric method. Ann. ent. Soc. Am. 62, 925-927.

Johnson W. T. and H. H. Lyon (1976) Insects that Feed on Trees and Shrubs, p. 464. Cornell University Press, New York.

Martin M. M. and H. M. Van't Hof (1988) The cause of reduced growth of Manduca sexta larvae on a low-water diet: increased metabolic processing costs or nutrient limitation? J. Insect Physiol. 34, 515-525.

Mattson W. J. and J. M. Scriber (1987) Nutritional ecology of insect folivores of woody plants: nitrogen, water, fiber, and mineral considerations. In Nutritional Ecology of Insects, Mites, Spiders and Related Invertebrates (Ed. by Slansky F. Jr and Rodriguez J. G.), pp. 105-146. Wiley, New York.

Reese J. C. and S. D. Beck (1978) Inter-relationships of nutritional indices and dietary moisture in the black cutworm (Agrotis ipsilon) digestive efficiency. J. Insect Physiol. 24, 473-479.

Schmidt D. J. and J. C. Reese (1986) Sources of error in nutritional index studies of insects on artificial diets. $J$. Insect Physiol. 32, 193-198.

Schroeder L. A. (1986) Protein limitation of a tree leaf feeding Lepidopteran. Ent. exp. appl. 41, 115-120.

Scriber J. M. (1977) Limiting effects of low leaf water content on the nitrogen utilization, energy budget and Jarval growth of Hyalophora cecropia (Lepidoptera: Saturniidae). Oecologia 28, 269-287.

Scriber J. M. and P. Feeny (1979) The growth of herbivorous caterpillars in relation to degree of specialization and to growth form of food plants. Ecology 60, 829-850.

Slansky F. Jr and J. M. Scriber (1985) Food consumption and utilization. In Comparative Insect Physiology Biochemistry and Pharmacology (Ed. by Kerkut G. A. and Gilbert L. I.), Vol. 4, pp. 87-163. Pergamon Press, Oxford.

Timmins W. A., K. Bellward, A. J. Stamp and S. E. Reynolds (1988) Food intake, conversion efficiency and feeding hehavior of tobacco hornworm catepillars given artificial diet of varying nutrient and water content. Physiol. Ent. 13, 303-314.

Waldbauer G. P. (1968) The consumption and utilization of food by insects. Adv. Insect Physiol. 5, 229-288. 